\title{
Operationalizing intersectionality: an approach to uncovering the complexity of the migrant job search in Australia
}

\author{
Susan Ressia,* Glenda Strachan and Janis Bailey
}

This paper explores the complexities surrounding the lived experiences of skilled migrant women and men from non-English speaking backgrounds (NESBs) who arrive in Australia and attempt to seek work. The paper will analyze the migrants' experiences using intersectionality theory as a framework. Drawing on Anthias's social relations framework, this research will contribute to the field by demonstrating how intersectionality theory can be operationalized to understand the complex lived experiences of disadvantaged groups. The research will reveal how being a new migrant in Australia, unfamiliar with local job search processes, complicates jobseeking. The paper will show how gender and family roles impact this process, especially when young families are involved. Both genders suffer downward occupational mobility, with men seeking any type of work to get by, and women gravitating towards insecure forms of employment, or exiting the labour force, in order to manage the family unit.

Keywords: intersectionality, migrants, employment, Australia

\section{Introduction}

Tntersectionality is a relatively recent development within feminist theorizing. It aims to deepen our 1 understanding of the complexities associated with difference enabling the examination of how gender, race, ethnicity, class and other identities, including the migrant identity, are influenced by societal power differentials, creating complex multiple disadvantages for people of difference. Since Kimberlé Crenshaw's (1989) and Patricia Hill Collins's (1990) groundbreaking work, intersectionality theory has been widely canvassed in scholarly work (Özbilgin et al., 2011), but has had limited application to empirical research (Atewologun et al., 2016). Recently, however, researchers have been eager to remedy this problem, contributing thoughtful and insightful research as to how this theory can be applied and further developed. McCall (2005) is one of the early crusaders, providing a methodological approach to undertaking work in the intersectionality field. This research has been acknowledged by Davis (2011, p. 43) as being one of the 'most important contributions' made within the realm of women's studies. Davis (2011, p. 44) highlights that intersectionality has been debated in terms of whether it is a 'theory, concept or heuristic device', and suggests that the 'vagueness and openendedness of intersectionality theory may be the very secret of its success'. Lewis (2009) argues that it must be open to change (see discussion by Rodriguez et al., 2016). The recent work of Tatli and Özbilgin (2012) further advances intersectional approaches by utilizing Bourdieu's theory of capitals, with implications for the identification of site/s where inequality and disadvantage occur within the context of different forms of capital (i.e., social, cultural, economic and symbolic). Atewologun et al. (2016, p. 1) use identity work for 'analyzing/making sense of intersecting identities', focusing on

Address for correspondence: *Centre for Work, Orga 2 n and Wellbeing, Griffith Business School, Griffith University, Nathan Campus, Griffith University, Brisbane Qld 4111, Australıa; e-mail: s.ressia@griffith.edu.au 
macro, meso and micro levels of analysis of the sites where disadvantage occurs, as well as operationalizing intersectionality theory at the identity level.

Intersectionality interrogates societal power differentials, which create multiple disadvantages for people of difference (Author, 2014). The use of intersectionality theory in this paper aims to provide a Q5 framework to examine complex identities including gender, race, ethnicity, class and other identities, such as the 'migrant identity' to examine the lived experiences of skilled immigrant jobseekers in Australia. The focus considers the intersections of ethnic, professional and family identity, as the skilled non-English speaking background (NESB) migrant traverses an unfamiliar labour market. A gap has emerged in considering the operationalization of intersectionality theory in relation to the study of migrant outcomes. Scholars have highlighted that increasing numbers of self-initiated migrants are integrating into foreign labour markets (Gho \& Al Ariss, 2015; Dietz et al., 2015), but are still a group that is relatively under researched. Further, differences in outcomes between genders (Anthias, 2012b; Collins, 2000; Kofman, 2014; Kofman \& Raghuram, 2006) have been less explored compared to the male experience (Boucher, 2006; Cobb-Clark et al., 2001). Despite the increases in female mobility around the globe (Docquier et al., 2009; IOM, 2010; Kofman, 2004, 2014), it appears however, that women continue to experience lower employment participation rates than men (Cobb-Clark, 2000; Webb et al., 2013).

This paper also seeks to advance and operationalize intersectionality at the individual level of the skilled migrant, using Floya Anthias's (2012a, 2012b) social relations framework. While there is no one clear definition of intersectionality theory, Anthias believes that intersectionality is a 'heuristic device' where it is used to enable understanding of how 'social divisions interrelate in terms of the production of people's lives' and experiences (Anthias, 2012b, p. 4). While Australian immigration policy suggests that skilled migrants, regardless of background should experience better employment outcomes due to the emphasis on skilled migrant intakes (Hawthorne, 2005; Mahuteau \& Junankar, 2008; Teicher et al., 2002), thus suggesting improvements in economic outcomes (Chiswick et al., 2005; Connell \& Burgess, 2009; Groutsis \& Arnold, 2012), little attention has been paid to the specific experiences of women migrants, the impact of skilled immigration policy, and their subsequent jobseeking experiences (Kofman, 2014; Kofman \& Raghuram, 2006). Therefore, Anthias's framework is used to gain a deeper understanding of the difficulties they experience and why. The paper contributes a nuanced understanding of the challenges migrants experience as they settle in Australia, and may go some way towards addressing the need for operationalizing intersectionality research within 'micro-level encounters, structures, systemic process and institutional arrangements' (Rodriguez et al., 2016, p. 205).

The paper is constructed as follows. First, it provides an overview of the intersectionality literature, with an explanation of Anthias's social divisions, social relations and social locations framework. Second, the method and data section describes the research process undertaken, involving semistructured interviews with 22 migrant participants on two separate occasions, one year apart. Anthias's (2012a, 2012b) framework is then applied to explore how the social divisions of ethnicity, gender and 'new migrant status' affect migrants' job search experiences, leading for most to downward occupational mobility. This research therefore provides a model for using intersectionality to examine NESB skilled migrants who are permanent settlers and are new to the Australian labour market. The paper makes a contribution towards the operationalization of intersectionality, utilizing empirical data, to advance the development of a theoretical framework and to progress intersectionality theory in terms of understanding the issues of groups who are vulnerable in unfamiliar labour markets.

\section{Intersectionality theory}

Intersectionality theory is a feminist sociological approach to the operation of individuals, groups and societies that takes into account multiple sources of individual identity (Adib \& Guerrier, 2003; Benschop, 2006). The theory was initially prompted by the observation that studies of women's inequality rarely disaggregated data by race, thus privileging white female experiences (Browne \& 
Misra, 2003). The particular value of intersectionality theory, as Acker (2006) argues, is that previous research generally focused on a single category or 'social division' singling out gender, race, ethnicity or class, with little research on the intersections between them. This is evidenced by Black feminists and feminists of colour who originally set out to challenge the dominant 'women, white and middle-class' vein of feminist scholarship in the 1970s and 1980s, and argued that feminism did not adequately explain other women's experiences of discrimination and difference. Early forms of theorizing undertaken by groups such as the Combahee River Collective in the United States (US) (Mann, 2013; West \& Fenstermaker, 1995) has since been extended by Black women scholars including Kimberlé Crenshaw, Patricia Hill Collins and bell hooks. These authors argue that Black women face issues other than gender differences, and that theoretical models are required to help explain their experiences of gender and race (hooks, 2001). Hence theorizing around the multiple identities that people possess using the notion of intersectionality has become an important means of exploring discrimination and unequal treatment.

Developed from an analysis of the US legal system and the anti-racism movement, Crenshaw argued that in cases of discrimination in employment, the constructs of gender and race were always treated separately (see Crenshaw, 1989; MacKinnon, 2013). Crenshaw however stated that such factors were 'intersectional' rather than separate from each other or, as Lewis (2009) puts it, merely 'additive'. Patricia Hill Collins (1990) expanded the terrain of Black feminist theory by demonstrating how a person's standpoint was ingrained in their social location (Baca Zinn, 2012; Higginbotham, 2012). In sum, Crenshaw's and Collins's work expanded theorizing in 'racial inequality, social stratification and feminist thought' and laid the ground for new kinds of empirical research (Baca Zinn, 2012, p. 30).

Theorists later began to argue that focusing only on the three constructs of gender, race and class was not sufficient to fully analyze oppression and inequality, arguing that other identities might be implicated (Walby, 2011). This resulted in a shift from 'additive notions' of race, gender and class (Lewis, 2009, p. 205) to a more sophisticated theory that acknowledged how broader societal systems influence and create disadvantage for people not in privileged locations or positions (Anthias, 2012a, 2012b; Weber, 2010). Understanding the lives of individuals is therefore critical to understanding how disadvantage occurs, as people occupy varied positions that intersect with one or many of the socially constructed characteristics of identity. As a result, intersectionality theory has broadened its reach in that, increasingly, the broader 'socio-cultural position of underprivileged groups' (Bürkner, 2012, p. 182) has become the focus of research.

Intersectionality as a theory, method or focus of analysis has been considerably modified and developed since it was first introduced, and is now much more nuanced and concerned with social location. Leslie McCall's (2005) work highlighted that little attention has been paid to the complexity of intersectionality and discussed three approaches observed in the literature - 'Anti-categorical; intercategorical, and intra-categorical' - and explained how each approach produces differences in knowledge (McCall, 2005, pp. 1773-4) (for further explanation, see McCall, 2005 as well as discussion by Wright, 2016). Significantly, the scholarship of Floya Anthias explores social divisions and categories and analyzes how they operate within various social contexts and delivers 'outcomes of differentiation' (Anthias, 2012a, 2012b, p. 102; 2012c). This seminal work helps to explain how disadvantage is created within contexts, and illuminates the complexities of people's lived experiences, especially those of vulnerable individuals and groups.

In this paper, Anthias's concepts of social divisions, categories and their relationships to wider social systems and processes provide the analytical framework to explore how ethnicity, migrant status, gender and family status intersect within specific social relations contexts. Anthias argues that social divisions interrelate to produce social relations, and as these interactions play out they affect people's lives in significant ways (Anthias, 2012b). The Australian labour market provides the broader 'social relations' context for the way in which social divisions and categories produce disadvantage for the research participants in this study, and produces their subsequent 'social location' (or outcomes) in lower level occupations.

Social divisions refer to the 'central' economic and social status of individuals. Anthias defines social divisions as involving the 'classification of a population ... which serves to produce socially 
meaningful and systematic ... practices and outcomes of inequality' (Anthias, 2001, p. 837). Divisions refer to class structures, as well as gender and race (Anthias, 2001, p. 836). This has commonalities with Tatli and Özbilgin's (2012), 'emic approach' underpinned by Bourdieu's theory of capitals. While the context of their research focused on workplace diversity, this approach considers emergent categories of difference, which develop understandings that arise through the specific context of investigation. Such an approach attends to the 'temporal and geographic contextual relations of power, privilege, inequality and disadvantage' (Tatli \& Özbilgin, 2012, p. 181). Anthias's (2001) approach can be used to explain individuals' and groups' social location(s) and outcomes at the micro level, to emphasize that positions and locations are fluid and dynamic (see Figure 1).

Research shows that achieving good employment outcomes for skilled NESB migrant women and men is problematic, and is the case internationally (Dyer et al., 2010; Fang et al., 2009; Liversage, 2009; Turner 2010) as well as in Australia. Migrants' acquired skills, qualifications and knowledge are often underutilized or not fully recognized, resulting in skilled migrant women ar pen often being forced to accept work in lower-skilled jobs unrelated to their profession (Groutsis ; Raghuram, 2008) and thus engaging in a spiral of 'downward occupational mobility' (Ho, 2006). Women in particular, face difficulties in finding appropriate work, suggesting that gender plays a large role in determining their access to employment. Explanations for this lie in social structures such as the division of labour within households, which emphasizes the gendered roles of the male as breadwinner and female as homemaker (Alcorso \& Ho, 2006; Beauregard et al., 2009; Campbell et al., 2009, Kofman \& Raghuram, 2006; Meares, 2010). The age of children also plays a role in the employment outcomes of skilled migrant women, with mothers of younger children facing particular difficulties (Author, 2014). Within this context, this research applies Anthias's work, operationalizing intersectionality the- Q6 ory by analyzing the lived experiences of skilled migrant women and men seeking employment in Australia, exploring relevant social divisions, categories and social relations and how they intersect in producing outcomes.

\section{Method and data}

The research reported in this paper comes from a recent $\mathrm{PhD}$ research project on the employment expectations, experiences, and outcomes of permanent skilled migrant settlers from NESBs. Participants for this study were recruited via migrant support and advisory organizations and networks in the public and community sectors. This included one state government and one local government

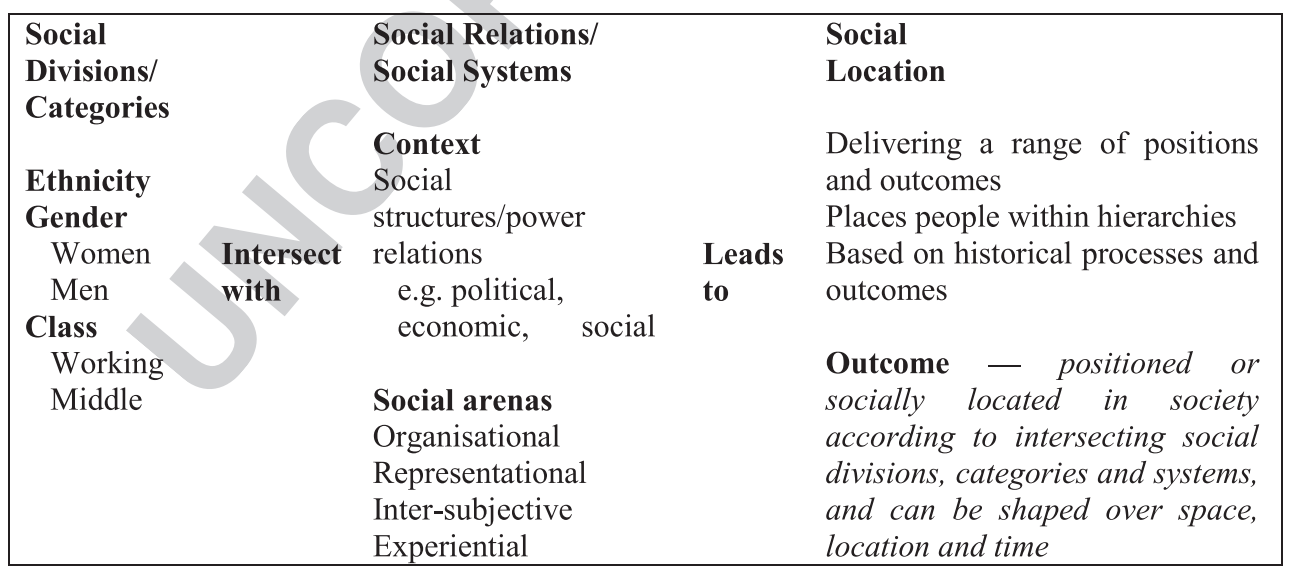

Figure 1: Model of Social Divisions, Social Relations and Social Location Adapted from Anthias (1998, 2001, 2012b) 
organization, as well as two community-based organizations in Australia. One participant was recruited by 'word-of-mouth' after hearing about the research. Additional government and community-based organizations were contacted to increase the number of participants however, recruitment ceased after nine months.

Semi-structured interviews were conducted to enable participants to share their lives and events through telling their own stories (Bryman, 2004). In addition, some of the participants recounted their spouse's job search experience, and these experiences have been included in this research. Twentytwo participants took part in two phases of data collection - two face-to-face interviews 12 months apart. Seventeen participants were female and five were male. Phase 1 of the research took place in 2009, and Phase 2 in 2010. Interviews were approximately an hour in length. Narrative analysis was used to explore participants' stories in a systematic way, with major themes developed using grounded theory techniques (Charmaz, 2000). The participant group were very diverse, originating from 16 countries, and included professionals from a wide range of skilled occupations including engineering, teaching and accounting (see Table 1). In addition, the research identified that participants $\mathbf{T}$ had been in Australia for varying lengths of time, adding another dimension to the research where two groups emerged: 1. Early entrants (defined as skilled migrants who had been seeking work for a period of one year or less); and 2. Experienced jobseekers who had resided in Australia for over one year. This time dynamic is explained in a paper written by the authors (see Authors, 2016).

As can be seen in Table 1, most of the skilled migrants had a high level of education, and experience in their occupation prior to arriving in Australia. Participants were at different stages in their employment search, mainly due to the length of time since arrival. At the first interview, nine participants were unemployed, five were in job placement programmes, and eight were employed. At the second interview, employment outcomes had improved marginally in that more participants had obtained employment, although the jobs gained were generally not commensurate with participants' skills and qualifications (see Table 1). An important distinction to make at this point is that while this research focused on the experiences of seeking work and the processes the participants undertook, the study did not focus on differences between each skilled migrant due to their work experience and skill level. The perspective of this research considers the individual and their expectation of finding commensurate employment, rather than providing insight about the similarities or differences between the different occupations. The premise here is that each individual experiences an outcome contrary to their expectation. Therefore, intersectionality theory is operationalized to explain this phenomenon.

\section{Operationalizing the research}

Three social divisions are identified and analyzed in terms of their impact on participants' jobseeking outcomes (see Table 2). Anthias's divisions of ethnicity and gender are the first two major sites of fo- T2 cus for the analysis. Further sub-categories were developed to analyze women's experiences of family responsibilities, to show differences between women with and without children. A new social division 'new migrant status' has been introduced as a result of this research. New migrant status refers to migrants' newness to, and lack of knowledge about, labour market processes. These three divisions — ethnicity, 'new migrant status' and gender — along with their associated categories, shaped outcomes for the participants in this study.

\section{Social division of ethnicity}

The study reveals that most participants experienced problems finding work due to their ethnic background and origins. For example, speaking a different language, having non-Australian qualifications, and having no 'local' work experience were significant problems. Many of those interviewed perceived lack of English language fluency to be the biggest barrier to their employment. Lack of 'local' work experience was also a significant challenge and frustration. Khalid, an Iraqi man, for example, was unsure as to where he could gain local experience when, despite significant effort, he could not 


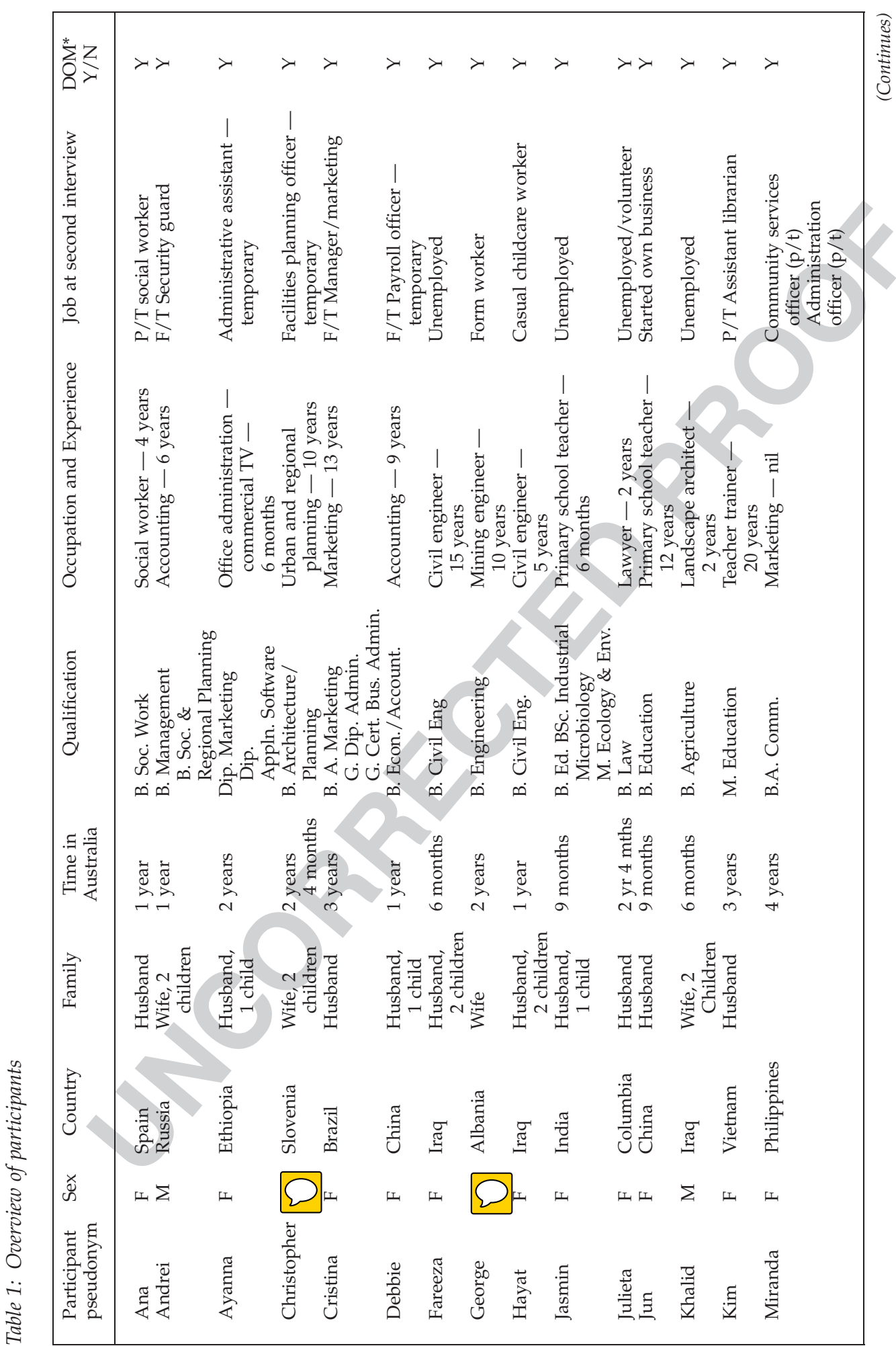




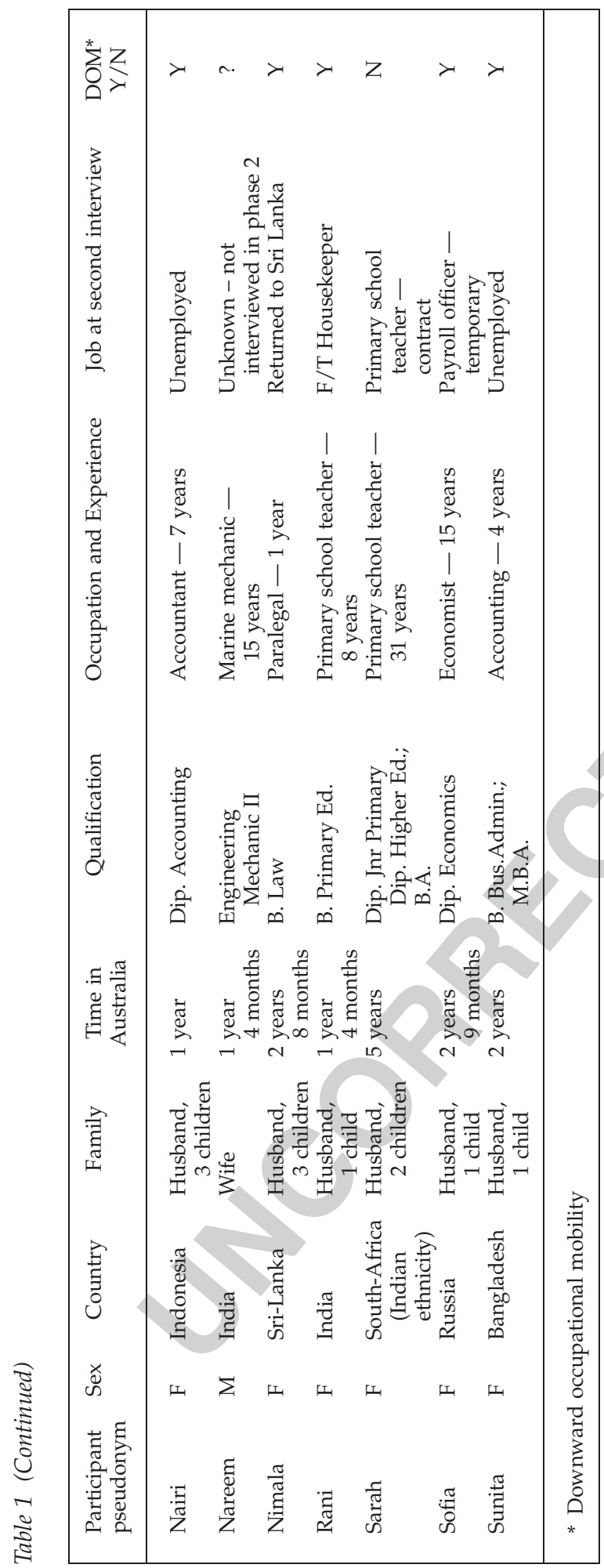


Table 2: Overview of social divisions, social categories and sub-categories

\begin{tabular}{|c|c|c|}
\hline Social divisions & Social categories & Sub-categories \\
\hline $\begin{array}{l}\text { Ethnicity } \\
\text { New migrant status } \\
\text { Gender }\end{array}$ & WomenMen & $\begin{array}{l}\text { Women with young children no supportWomen } \\
\text { with young children and support } \\
\text { Women with older children } \\
\text { Women with no children }\end{array}$ \\
\hline
\end{tabular}

secure a job. Christopher, a Slovenian man, also spoke of his frustration, noting that it was hard for him to convince employers that there were no differences between the particulars of a job he did overseas, and similar work in Australia: 'It was always hard for me to convince potential employers ... [that] there is not so much difference as they think between Europe and Australia in this respect.'

Recognition of overseas qualifications also caused difficulties. Most participants found that their qualifications were not fully recognized, or that they required additional training. Hayat, an Iraqi woman, reported difficulty because her qualification was perceived as being too specialized. Participants said that their job applications would often go unanswered, as George explains:

[I have heard] nothing, nothing at all ... No one can tell you what you have experience or not. [My job application may go] straight in the bin! Or, I ... apply a lot from my computer, and they [perhaps] delete it.

The research confirms others' findings that NESB skilled migrants experience problems with their transfer of skills, leading to poor employment outcomes (Bertone, 2009; Booth et al., 2010; Liversage, 2009; Misko, 2012). This contradicts community expectations — and the expectations of migrants themselves - that Australia's current immigration policy, with its emphasis on addressing skill shortages in the labour market, will result in positive employment outcomes for all skilled migrants (Almeida \& Bertone, 2013). While not all skilled migrants struggle quite as much as the individuals within this study, participants are broadly representative of a large pool of underemployed (and unemployed) migrants. Government statistics (ABS, 2011) show that 28 per cent of skilled professional migrants (e.g. teachers, civil engineers and accountants) experience a change in occupation after arrival. The results of this study mirror previously well-documented barriers including language, recognition of skills and qualifications, and lack of local job experience and familiarity with the labour market (Alcorso \& Ho 200 Bertone, 2009; Birrell \& Rapson, 2005; Chiswick et al., 2005; Colic-Peisker \& Tilbury, 2007; Groutsis, Vasta, 2005). Published studies suggest that the process of transferring migrants' experience, qualifications and skills into the Australian labour market is problematic (Castles et al., 1998; Ho, 2006; Hugo 1994; Wooden, 1994) resulting in poor employment outcomes for migrants (Almeida et al., 2012; Booth et al., 2010; Chiswick et al. 2005; Hawthorne, 2005; Ho \& Alcorso, 2004; Syed, 2008; Webb et al., 2013). Further, restrictions have been placed on the ability of migrants accessir $\bigcirc$ ofessional jobs, by employer bodies, which is contrary to broader policy requirements (see Groutsis there are significant issues surrounding the acceptance of NESB migrants into the labour force. Thus the social division of ethnicity is an important point of focus in understanding the outcomes of NESB skilled migrants within the social arena of the labour market.

\section{Social division of 'new migrant status'}

A key finding of the research is that some issues are specific to participants' recent arrival, adding additional complexities. Therefore, 'new migrant status' as a further social division is particularly 
pertinent for these participants. 'New migrant status' can be used to er nn why NESB skilled migrants experience particular challenges as a result of migration (Forout 2 1008). 'New migrant status' is a complex notion but, in the context of job searching, involves migrants' under-developed knowledge of Australian social systems and norms, including the informal and unspoken rules that govern job hunting (Webb et al., 2013), and the supports available to jobseekers.

Specifically for NESB skilled migrants, this research shows that most participants did not know, at least initially, how to apply for jobs, write applications and produce résumés, a process familiar to most of the local population. This lack of knowledge hampers migrants' first attempts to find work, resulting in frustration at not getting interviews. For example, Ana, from Spain, remarked that writing a CV was a completely different process from what she had been used to. She felt uncomfortable with having to 'sell yourself' in a competitive job market:

Here [in Australia] I think it's more competitive in some ways [to get a job] but also it's in my opinion, it's more fair in some ways cause it's kind of, I mean, you have to sell yourself. That's what it's an interview for. But in Spain it is not like that because we feel some kind of shame of saying I know how to do this, I know to do that and selling yourself you have to be kind of [forward]. Here ... you have to sell yourself but not lying or exaggerating anything at all, so you really have to make sure that the selection criteria are adjusted or if there are something that you don't know, you will be able to reach those skills ...

Christopher, from Slovenia, describes the problems he encountered understanding the way jobseeking actually worked. Fareeza and Khalid, from Iraq, found that preparing a job application was quite complex compared to their experience in their home country.

Another key factor that hampered migrants' acquisition of local knowledge was that most lacked social networks, supporting the findings of others (for example, Dyer et al., 2010; Ho, 2006). Even those few participants who had friends or relatives already residing in the areas that they had migrated to found that these connections did not provide assistance with finding employment, as they were usually in the same position of attempting to traverse the job search process (Cederberg, 2014). Jasmin explained that her friends were too busy with their own studies and employment to be of assistance. This, however, was in contrast to Christopher's experience. He was able to gain employment through a friend of his wife, whose husband had previously lived in Slovenia. Similarly, Cristina came to know about a job through a chance meeting at a social function. Some, like Miranda and George, saw the importance of forming new connections, and viewed further study as a mechanism for this. Miranda explains her experience:

I did the whole cleaning, sandwich making ... for about a year, and then when I had enough of it, I said, 'Ok, while I was doing the cleaning and stuff I was also looking for a job in communications. ... I couldn't even get to an interview level' ... after a year of that I was like, 'Ok, I'm over it, I just need to find connections'.... I thought that the best way to find these people was at a university, so I thought, Ok, jump into a postgrad degree.

The findings illustrate that participants' limited understanding of local systems and lack of social networks contributed to their 'new migrant status'. For instance, many participants were either not aware of work placement programmes that could equip them with jobseeking skills, or took some time to discover them. While there is limited literature on these issues, the findings of Dyer et al. (2010) and Ho (2006) suggest that limited knowledge of local systems and loss of social networks create challenges for mig 1 , as well the discriminatory practices observed of professional bodies and employers (Groutsis, ding further complexity and issues of fair practice when accessing employment opportunities (Syed, 2008). The analysis above bears out Anthias's contention that the operation of social divisions intersects with the social relations of the labour market (Anthias, 1998, 2001, 2012a). The social division of ethnicity has categories, including language, skills, work experience, appearance and culture that affect how individuals experience the job search process and influence outcomes. Additional insights are provided by adding the social division of 'new migrant status'. 


\section{Social division of gender}

The third social division critical for participants in this study is gender. Work and family influences were also incorporated into the analysis to examine the gendered effects of decision-making around work and family care. Importantly, the research included the perspective of the male skilled migrant, drawing upon the masculinity literature to consider the impact of the migration process in shaping women's and men's post-migration identity. Examining these intersections provide further insights into the complexities of the skilled migrant job search experience.

\section{Social categories of women and men}

All research participants, female and male, were ready to work in their chosen field. Both women and men were equally keen to continue or re-establish their careers, and were initially confident that the combination of their skill sets and qualifications were a firm basis for their new lives and for meaningful employment. Fareeza, a civil engineer from Iraq, expressed her passion for continuing in the career that she loved. Hayat, also a civil engineer from Iraq, was excited about new opportunities that would broaden her experience. The men were also very determined to find equivalent employment even though they were aware it might take some time. Nareem was keen to 'develop himself' and learn from 'another culture' while George, a mining engineer, took various jobs for economic security as well as to gain local experience.

Importantly, the women did not want to be considered economically dependent on their male partners. The research findings, however, clearly demonstrate a shift in this gendered perception of skilled migration, where historically, males were the primary applicants in the immigration process and women were classed as secondary. In more recent times, the number of primary female applicants has begun to equal or even exceed males (Donato et al., 2006; Kofman, 2004; Syed \& Murray 2009). For example, Jasmin and Debbie arrived on skilled independent visas with their families, and were the 'primary migrant'. In addition, it is important to note that the partners of male primary migrants were also highly skilled and determined to find good jobs. However, while both women and men skilled migrants are found to be equally motivated in achieving commensurate employment, gender can operate in ways to produce very different outcomes to what they had originally expected.

\section{Social category of women}

In most cases where both partners were skilled professionals, it was clear that jobseeking strategies differed with respect to gender. Partners communicated with each other, often extensively, about the job search process, and couples were supportive of their partner's aspirations. However, social norms concerning the breadwinner role shaped jobseeking behaviour and resulted in gendered outcomes. This particularly occurred when employment seeking became difficult for both parties, and decisions about balancing the conflicting responsibilities of work and family had to be made (see Pocock, 2003, 2005). The research clearly demonstrates that, in most cases, it is ultimately the woman who bears the major responsibilities of settlement and caring for the family, even when she is the primary migrant. Not surprisingly, this negatively affects her search for work. For example, Nairi wanted to ensure that her children were settled in a good school before she attempted to seek work. Similarly Sunita - who was trying to find work at the same time as her husband — revealed that her plans to seek skilled work were thwarted when her husband found work as a manager of a fast food restaurant, and she became responsible for the care of her young child. Nimala and Rani were also constrained as their husbands sought work out of economic necessity to provide a family income and contribute to the purchase of a home. It is clear that women were much more likely than men to take on the caregiver role, which is detrimental to women pursuing their careers.

A further aspect of the gendering of the job search process was that women were more resigned towards taking jobs (if they could get them) in fields outside their profession, simply to provide 
additional financial support to their families rather than to contribute to their own 'self-actualisation' (Pedraza, 1991, p. 313). For example, Jasmin, Rani and Sunita reported that their employment, even if it was in low-paid work outside their field, was important for the economic stability of the family. Hayat, a civil engineer, became a childcare worker. Nimala, a paralegal, looked for work at a local supermarket, while Rani, a primary school teacher, became a housekeeper at a city hotel. Compromises like these have implications for women's mental health, stress levels and self-belief (Bertone 2009; Boyle et al., 2009), as is evident in Hayat's story:

I'm not happy ... I lost my job and I, I'm from civil engineering [and have moved] to childcare. I'm not happy ... I lost all my [design] skills. ... I couldn't find a work placement ... [or] volunteer ... I think [if] the ... government can offer us any courses or work placement this will be ok. Maybe that can change our life here ... because our life is very difficult and I'm still young.

In addition, a number of women reported that they had found it difficult to secure childcare due to financial constraints. It therefore appears that socially constructed societal factors interact, becoming problematic for skilled migrant women (Andersen, 2005; Grasswick, 2006; Kofman, 2005; Smith, 2004) as well as for men in relation to decision making around employment and family care. This provides further evidence that migration is a highly gendered process. The findings also reveal that migrant women experience very different outcomes based on whether they have children or not. This created an additional sub-category that divided women's experiences around family responsibility.

\section{Sub-categories of women}

The study revealed differences between the jobseeking experiences of different types of women, depending on whether they had children or not. The ages of the children also mattered, as younger children required more hands-on care and emotional support (Foroutan, 2008) than older children. When extended family support was not available, and financial constraints restricted access to paid childcare, a woman's ability to seek work was further impeded. This is a key finding of the research, and has demonstrated that women, especially those with young children, are constrained around mothering and the intensity of home-making and caregiving roles, a source of significant disadvantage for women (Cooke 2007; Zaiceva 2010), as Sunita explains:

When I came here [to Australia], my son was only 14 months and ... my husband was [a] student. I have not that much mental strength or financial strength to put him in the childcare, because the childcare is very much expensive.

The research identifies four distinct groups of women: women with young children who had little support; women with young families who received substantial family support; women with older children; and women without children (see Table 3, which presents each sub-category and each fe- T3 male's pre-migration occupation, their expectations for finding work, and their initial employment experience). Women with young children having limited access to formal childcare and lacking support from family networks, had particularly fraught jobseeking experiences, consistent with the findings of others (Sang et al., 2013; Webb et al., 2013). The study also reveals differences between women, especially in the case where mothers have the advantage of help from extended family. Women without children were the least constrained. Similarly, women with older children were not as tied to hands-on caregiving as women with younger children. These women found seeking work less fraught, and had greater flexibility in their search for employment. The researchers found that each woman discussed her own experiences of jobseeking, and for some, it was evident that it was easier to make choices or develop strategies than for those who had children. Women with children included discussion about family and the care of children when talking through their strategies for finding work, as Nimala who has three young children explains: 


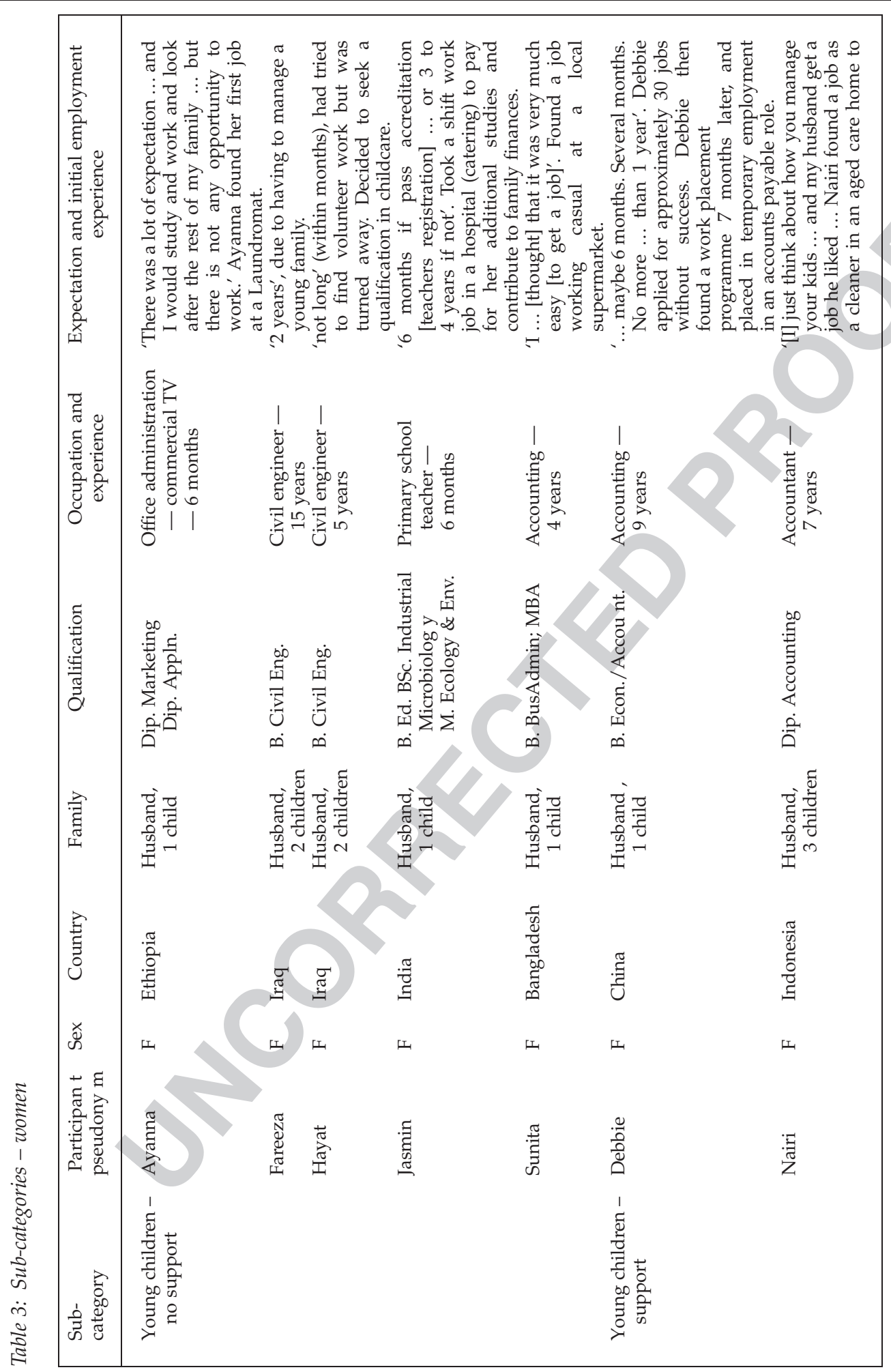


3

4

$\frac{5}{6}$

7

8

$\frac{9}{10}$

11

$\frac{12}{13}$

14

$\frac{15}{16}$

17

18

20

21

22 
[I have to] consider ... to work part-time. I just can't work-full time you know with three kids ... [but] I really have to work. We have bought this house, so my husband really needs my help with employment ... so it is not easy.

\section{Social category of men}

Like the women, the men arrived with human capital that they expected would enable them to find jobs easily in their profession, but out of necessity they would accept any kind of employment, as has been found in other studies (for example, Bertone, 2009). Nareem, a marine mechanic from India, drove a taxi to support himself and his wife, as she was experiencing difficulty securing work. Andrei, an accountant, found shift work as a security officer. Hayat and Rani's husbands, as well as Khalid and Nareem, undertook security courses at technical college. These strategies seemed to offer some hope and were important steps towards providing financial security for the family. However, choices around work become constrained (Miller, 2011) due to migrants' ethnicity, limited local work experience and underdeveloped labour market knowledge, and the male participants were left feeling frustrated and disappointed by the operation of these factors. As Rani explained, her husband Naveen's change in occupation from a production engineer to a security officer left him really defeated:

He got really frustrated, really frustrated [looking for work], and then he got a job, [after] he did [a] security course ... so he is working in security for money ... not job satisfaction.

The strain of this situation affected men in three related ways. First, the men faced the loss of their occupation and status. Second, they felt responsible for financial provision to the family, but at the same time they suffered insecure working conditions and lower pay than they would have had in a professional job. Third, they were continually seeking to regain employment in their chosen career. Additionally, there were cultural factors, such as the expectations on Nareem as the eldest son in his family. He said, 'I cried from my heart' over this frustration. Too ashamed to tell his parents of his circumstances and not wanting to burden them with his own suffering, he pretended that he was 'doing well'.

Unlike their female partners, males appeared less constrained by care responsibilities, and had more freedom to seek work. The men were strongly committed to the socially ascribed, gendered role of 'breadwinner' (Chesley, 2011; Hibbins, 2005), thus conforming with socially and historically constructed patriarchal and structural norms (Miller, 2011). These findings illustrate that the breadwinner role is important in shaping the male identity, which is deeply rooted in production relations and is part of the broader social construction of western patriarchy (Catalá et al., 2012; Donaldson \& Howson, 2009; Kofman, 2004). The adult male role and identity is synonymous with responsibility as the economic provider for the family (Anthias, 2012a; Miller, 2011). Importantly, the process of migration reshaped men's occupational outcomes and identity. The migrating male - whatever his skills and previous work experience - has to consider taking on any form of work to provide for the family in order to conform to the 'breadwinner' norm. However, as Andrei explained, finding initial employment was the first step in moving towards regaining employment in their occupation of choice.

While migrant men are seemingly subordinated by ethnicity and other factors within the public realm of employment, their role as providers of financial security for the home and family are undiminished and thus highly gendered (Anthias, 2012a; Connell, 2005). In contrast, the gendered norms surrounding a woman's role meant they were more likely than men to change their career trajectories due to the competing demands of family, study and (often low-paid) work, which reflects the ways in which the migration process reshapes gender roles and employment outcomes.

\section{Outcome: the experience of downward occupational mobility}

Despite possessing the skills and attributes required to meet rigorous immigration requirements, and their occupations being listed on the Migration Occupations in Demand List (MODL) or the Skilled Occupations in Demand List (SOL), this group of NESB skilled migrants did not achieve the 
employment they expected. The research showed that every participant suffered downward occupational mobility, and were unable to develop their professional careers (see Table 1).

\section{Impacts and effects on employment}

Drawing on the analysis of the social division of gender and associated social categories and subcategories, the research findings indicate that women with younger children were more likely to be out of work for lengthier periods of time than women with older or no children, or men. Hence they feared that they would never return to the profession they loved. Participants worried about the loss of occupational skills, and lost confidence in their jobseeking capacity. Women who had access to family support to assist with care needs appeared better equipped to manage the juggle of work, care and (often) study. However, they knew it would still take time to re-establish employment in their occupation. In contrast, women without children had more independence in fulfilling their career goals. Despite this, they still faced challenges complicated by their ethnicity, new migrant status and gender. Work was considered a major part of their identity both financially and professionally. Women with older children, while still responsible for the home, balanced these dual roles more easily as the levels of care required were less intense. Thus, consistent with the findings of others (Boucher, 2006; Mushaben, 2009), women with younger children appeared the most likely to experience permanent career damage.

It is clear from the negotiations that take place within couples that the male participants sought employment due to straightforward economic necessity, but women's jobseeking strategies were somewhat more complex. While both sexes applied an array of 'career self-management' strategies (Fang et al., 2009, p. 474), men usually found work in more male dominated sectors within the lower end of the labour market, but appeared determined to build upward from this over time. The women, however, were more likely to take any form of work to aid with family finances, and/or contemplate a permanent career change to more feminised, lower-paid and insecure occupations (Bertone, 2000, 2009). These decisions are clearly tied to family circumstances and have ongoing damaging effects on women's career trajectories (Cooke, 2007; Liversage, 2009).

The focus of this analysis was developed from Anthias's framework, and focused on the identified divisions of ethnicity, 'new migrant status' and gender, and within gender, the categories of women and men, and the sub-categories of women based on family responsibilities. The research shows that participants' outcomes were not as they expected pre-migration, and all of the individuals experienced downward occupational mobility - if they obtained employment at all (see Figure 2). In addi- F2 tion, differences in social location were also apparent, particularly those based on gender as explained above, revealing how migrants' lives are shaped in ways that subordinate them within labour market hierarchies (Anthias, 2012b, 2012c; MacKinnon, 2013).

\section{Conclusion}

While there has been considerable expansion and development of intersectionality theory, there is still limited research operationalizing it (Atewologun et al., 2016). This study attempted to address this gap by drawing on the social relations framework developed by Floya Anthias (Anthias, 2012a, 2012b). By studying skilled migrant jobseekers in the context of the Australian labour market. Anthias's theory was operationalized by utilizing specific social divisions and categories as sites of investigation, so that migrants' experiences could be analyzed in the context of wider social systems. The analysis focused on the divisions of ethnicity, 'new migrant status' and gender, and within gender, the categories of women and men, and the sub-categories of women based on family responsibilities, and as such, we present a more holistic contribution to knowledge (McCall, 2005). The first social division, ethnicity, shows how migrants' job search is associated with problems stemming from the recognition of skill levels, qualifications, experience and English language fluency. The second social division, 'new migrant status', allowed us to explore additional complexities that arise for skilled migrants due to their lack of understanding and knowledge of local jobseeking practices. In addition, 


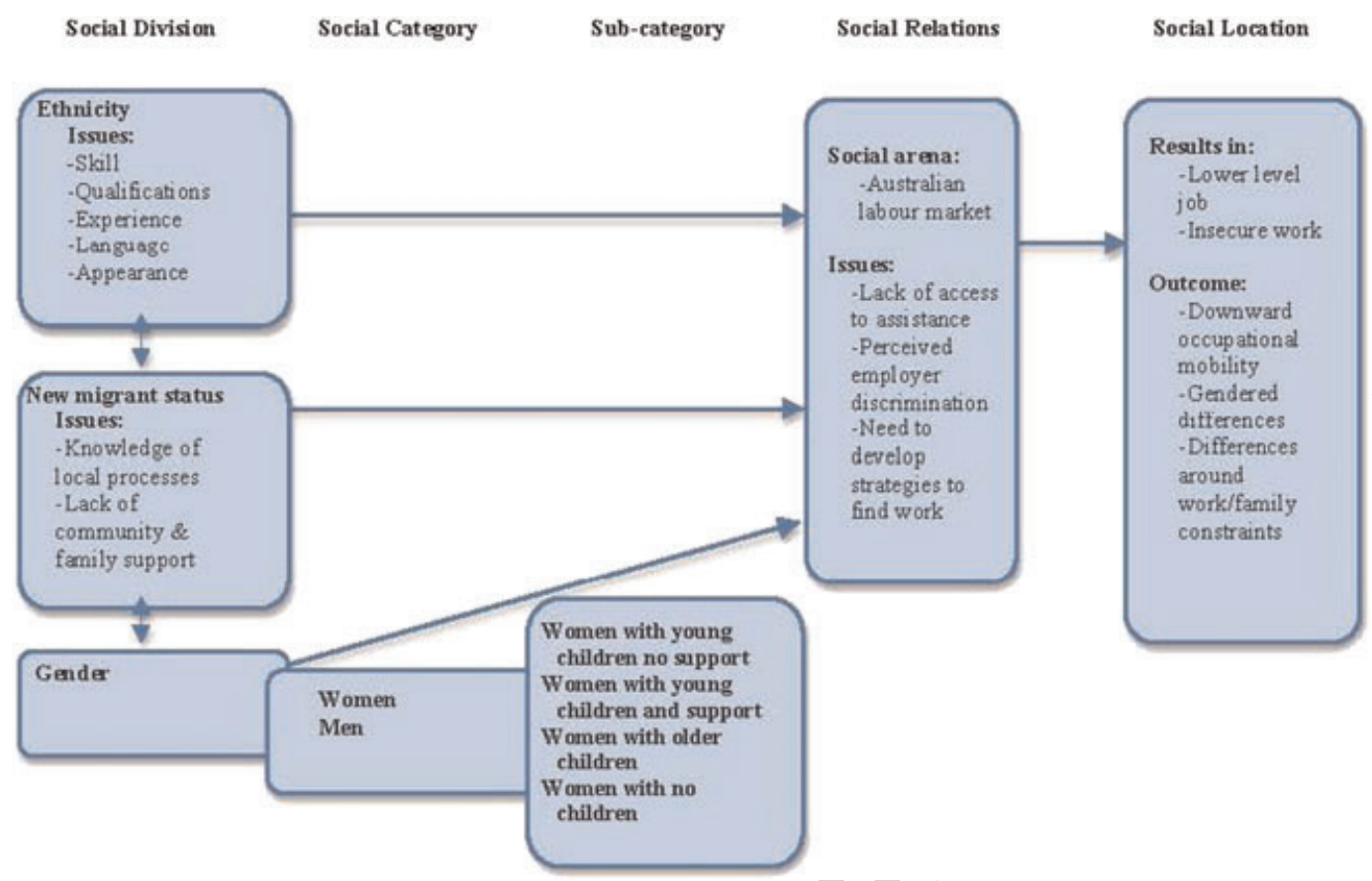

Figure 2: Overview of intersections for NESB skilled migrants, based on Anthias's (1998, 2001, 2012b)

the theory has enabled us to see that the additional loss of community and family support networks - associated with 'new migrant' status - also hinders the job search process for this group. The third social division, gender, not only enables consideration of differences between the experiences of women and men, but it also enables us to identify that additional differences between women are due to family responsibilities and the age of children.

The examination of these divisions, categories and sub-categories revealed that they intersect and create complexities for NESB skilled migrants as they seek work and show that the participants' outcomes were not as they expected pre-migration. Every individual in the study experienced downward occupational mobility in the labour market hierarchy — if they obtained employment at all. In addition, differences in social location also became apparent, particularly those based on gender.

Intersectionality is challenging and difficult to operationalize. Scholars continue to debate and work on advancing the field, yet there is still 'little agreement' on what intersectionality actually means when bringing an 'intersectional lens to the study of power, privilege and subordination ...' (Rodriquez et al., 2016, p. 204). This paper therefore contributes to further advancing the body of work on intersectionality studies. It is also acknowledged that the research has a number of limitations. Despite a lengthy recruitment process (nine months), only 22 participants volunteered to take part in this study. This could have been due to time constraints and the longitudinal nature of the study.

From this small sample size, we cannot generalize the experiences and outcomes to all NESB skilled migrants. Further, the study did not explore the experiences of skilled migrants who did not have difficulties obtaining good employment outcomes. Specific differences between individuals in terms of their ethnic or cultural backgrounds were not investigated, as this was outside the scope of this research project. However, it is envisaged that this work will lead to further discussion and development around building intersectionality frameworks that may help to explain the experiences and outcomes experienced by disadvantaged groups. 
The strength of the research is that it takes into account the differences in outcomes among women and men (Anthias, 2012b), and adds further understanding and knowledge about the experiences of migrant women, and their subsequent 'differentiated social positions that they occupy in the receiving country' (Anthias, 2012b, p. 106). This research thus acknowledges the complexity of the lived experience through the narratives (McCall, 2005) of skilled migrants presented within the social categories of race, ethnicity, gender, family and 'new migrant status' via the examination of concrete social divisions (Anthias, 2012a, 2012b). This makes an important theoretical contribution to the operationalization of intersectionality theory in analyzing the experiences, expectations and outcomes of skilled NESB migrant jobseekers. In addition, the research has important implications for policy and practice, in relation to understanding the complex disadvantage sk migrants face, in particular migrant women in relation to settlement and jobseeking (Groutsi Kofman, 2014). We highlight the need for policymakers to understand there is a continuing disconnect between certain migrant groups and access to good quality employment. We suggest that improved links be made between immigration processes and the identification of skilled migrants, which could match the skills that potential employers are seeking. The research also informs community service organisations and government departments of the difficulties experienced by these migrants on arrival, and the complexities that skilled migrants face in gaining employment due to the competing issues of finding work while managing settlement and family care. As this research shows, skilled migrants can end up in semi-skilled work not related to their original qualifications, which is a loss to the individual migrant and the receiving country.

\section{Declaration of conflicting interests}

The authors declared no potential conflicts of interests with respect to the authorship and/or. publication of this article.

\section{Funding}

This research received no specific grant from any funding agency in the public, commercial, or. not-for-profit sectors.

\section{References}

ABS (Australian Bureau of Statistics) (2011) Characteristics of recent migrants. Cat. no. 6250.0. Canberra: ABS.

Acker, J. (2006) Inequality regimes: gender, class, and race in organizations. Gender E Society, 20,4, 441-64.

Adib, A. and Guerrier, Y. (2003) The interlocking of gender with nationality, race, ethnicity and class: the narratives of women in hotel work. Gender, Work and Organization, 10,4, 413-32.

Alcorso, C. and Ho, C. (2006) Migrant women and the Australian information, communications and technology sector - a special case? Labour \& Industry, 16,3, 109-31.

Almeida, S. and Bertone, S. (2013) The influence of regional community characteristics on employer recruitment decision-making. Paper presented at the 5th International Community, Work and Family Conference, Sydney, 17-19 July 2013.

Almeida, S., Fernando, M. and Sheridan, A. (2012) Revealing the screening: organisational factors influencing the recruitment of immigrant professionals. The International Journal of Human Resource Management, 23,9, $1950-65$.

Andersen, M.L. (2005) Thinking about women: a quarter century's view. Gender E Society, 19,4, 437-55.

Anthias, F. (1998) Rethinking social divisions: some notes towards a theoretical framework. The Sociological Review, $46,3,505-35$.

Anthias, F. (2001) The concept of 'social division' and theorising social stratification: looking at ethnicity and class. Sociology, 35,4, 835-54.

Anthias, F. (2012a) Transnational mobilities, migration research and intersectionality. Nordic Journal of Migration Research, 2,2, 102-10.

Anthias, F. (2012b) Intersectional what? Social divisions, intersectionality and levels of analysis. Ethnicities, 13,1, 3-19.

Anthias, F. (2012c) Hierarchies of social location, class and intersectionality: towards a translocational frame. International Sociology, 28,1, 121-38. 
Atewologun, D., Sealy, R. and Vinnicombe, S. (2016) Revealing intersectional dynamics in organizations: introducing 'intersect identity $\rightarrow$ '. Gender, Work and Organization, 23,3, 223-47.

Auther (2014)

Authers (2016)

Baca Zinn, M. (2012) Patricia Hill Collins: past and future innovations. Gender \& Society, 26,1, $28-32$.

Beauregard, A.T., Özbilgin, M. and Bell M.P. (2009) Revisiting the social construction of family in the context of work. Journal of Managerial Psychology, 24,1, 46-65.

Benschop, Y. (2006) Of small steps and the longing for giant leaps: research on the intersection of sex and gender within workplaces and organizations. In Konrad, A.M., Prasad, P., \& Pringle, J. (eds) Handbook of workplace diversity. London: Sage Publications, pp. 273-98.

Bertone, S. (2000) Doing it tough: migrants and workplace change. In Bertone, S. \& Casey, H. (eds) Migrants in the new economy: problems, perspectives and policy. Melbourne: Workplace Studies Centre, pp. 46-78.

Bertone, S. (2009) Immigration and the labour market in Australia. In Higley, J., Nieuwenhuysen, J. and Neerup, S. (eds) Nations of immigrants: Australia and the USA compared. Cheltenham: Edward Elgar, pp. 86-99.

Birrell, B. and Rapson, V. (2005) Migration and the accounting profession in Australia. Melbourne: Centre for Urban and Population Research, Monash University.

Booth, A., Leigh, A. and Varganova, E. (2010) Does racial and ethnic discrimination vary across minority groups? Evidence from a field experiment. CEPR discussion paper no. DP7913. Available at: http://ssrn.com/abstract $=1640989$ (last accessed 17 June 2015).

Boucher, A. (2006) Skill, migration and gender in Australia and Canada: the case of gender based analysis. Australian Journal of Political Science, 42,3, 383-401.

Boyle, P., Feng, Z. and Gayle, V. (2009) A new look at family migration and women's employment status. Journal of Marriage and Family, 71,May, 417-31.

Browne, I. and Misra, J. (2003) The intersection of gender and race in the labour market. Annual Review of Sociology, $29,1,487-513$.

Bryman, A. (2004) Social research methods ( $2^{\text {nd }}$ edn). Oxford: Oxford University Press.

Bürkner, H. (2012) Intersectionality: how gender studies might inspire the analysis of social inequality among migrants. Population, Space and Place, 18,2, 181-95.

Campbell, I., Whitehouse, G. and Baxter, J. (2009) Australia: casual employment -time employment and the resilience of the male-breadwinner model. In Vosko, L., MacDonald, F.M. ar 2 mpbell, I. (eds) Gender and the contours of precarious employment. Abingdon: Taylor and Francis, pp. 60-77.

Castles, S., Foster, W., Iredale, R. and Withers, G. (1998) Immigration and Australia. St Leonards: Allen \& Unwin Pty Ltd.

Catalá, V.B., Colom, S.M., Santamaria, L.C. and Casajust, A.G. (2012) Male hegemony in decline? Reflection on the Spanish case. Men and Masculinities, 15,4, 406-23.

Cederberg, M. (2014) Public discourses and migrant stories of integration and inequality: language, power in biographical narratives. Sociology, 48,1, 133-49.

Charmaz, K. (2000) Grounded theory: objectivist and constructivist methods. In Denzin, N. and Lincoln, Y.S. (eds) Handbook of qualitative research $\left(2^{\text {nd }}\right.$ edn). Thousand Oaks, CA: Sage Publications, pp. 509-36.

Chesley, N. (2011) Stay-at-home fathers and breadwinning mothers: gender, couple dynamics, and social change. Gender and Society, 25,5, 642-64.

Chiswick, B.R., Lee, Y.L. and Miller, P.W. (2005) A longitudinal analysis of immigrant occupational mobility: a test of the immigrant assimilation hypothesis. International Migration Review, 2,Summer, 332-53.

Cobb-Clark, D. (2000) Do selection criteria make a difference? Visa category and the labour market status of immigrants to Australia. Economic Record, 76,232, 15-31.

Cobb-Clark, D., Connolly, M.D. and Worswick, C. (2001) The job search and education investments of immigrant families. Discussion papers. Canberra: Centre for Economic Policy Research, Australian National University.

Colic-Peisker, V. and Tilbury, F. (2007) Integration into the Australian labour market: the experience of three 'visibly different' groups of recently arrived refugees. International Migration, 45,1, 59-85.

Collins, J. (2000) Globalisation, deregulation and the changing Australian labour market. In Bertone, S. and Casey, H. (eds) Migrants in the new economy: problems, perspectives and policy. Melbourne: Workplace Studies Centre, pp. 13-45.

Collins, P.H. (1990) Black feminist thought: knowledge, consciousness, and the politics of empowerment. Boston: Unwin Hyman.

Connell, J. and Burgess, J. (2009) Migrant workers, migrant work, public policy and human resource management. International Journal of Manpower, 30,5, 412-21.

Connell, R.W. (2005) Hegemonic masculinity: rethinking the concept. Gender E Society, 19,6, 829-59.

Cooke, F.L. (2007) 'Husband's career first': renegotiating career and family commitment among migrant Chinese academic couples in Britain. Work, Employment and Society, 21,1, 47-65.

Crenshaw, K. (1989) Demarginalizing the intersection of race and sex: a black feminist critique of antidiscrimination doctrine, feminist theory and antiracist politics. University of Chicago Legal Forum, 138-67.

Davis, K. (2011) Intersectionality as buzzword: a sociology of science perspective on what makes a feminist theory successful. In Lutz, H., Vivar, M.T.H. \& Supik, L. (eds) Framing intersectionality: debates on a multi-faceted concept in gender studies. Surrey: Ashgate Publishing, pp. 43-54. 
Dietz, J., Joshi, C., Essers, V., Hamilton, L. and Gabarrot, F. (2015) The skill paradox: Explaining and reducing employment discrimination against skilled migrants. The International Journal of Human Resource Management, 26,10, pp. 1318-34.

Docquier, F., Lowell, B.L. and Marfouk, A. (2009) A gendered assessment of highly skilled emigration. Population and Development Review, 35,2, 297-321.

Donaldson, M. and Howson, R. (2009) Men, migration and hegemonic masculinity. In Donaldson, M., Hibbins, R. and Pease, B. (eds) Migrant men: critical studies of masculinities and the migration experience. New York, NY: Routledge Press, 210-18.

Donato, K.M., Gabaccia, D., Holdaway, J., Manalansan, M. and Pessar, P.R. (2006) A glass half full? Gender in migration studies. International Migration Review, 40,1, 3-26.

Dyer, S., McDowell, L. and Batnitzky, A. (2010) The impact of migration on the gendering of service work: the case of a west London hotel. Gender, Work and Organization, 17,6, 635-57.

Fang, T., Novicevic, M. and Zikic, J. (2009) Career success of immigrant professionals: stock and flow of their career capital. International Journal of Manpower, 30,5, 472-88.

Foroutan, Y. (2008) Migration differentials in women's market employment: an empirical and multicultural analysis. International Migration Review, 42,3, 675-703.

Gho, C. and Al Ariss, A. (2015) Human resource management of international migrants: current theories and future research. International Journal of Human Resource Management, 26,10, 1287-97.

Grasswick, H. (2006) Feminist social epistemology. Stanford University, CA. Available at: http://plato.stanford.edu entries/feminist-social-epistemology/ (last accessed 28 April 2011).

Groutsis, D.. The state, immigration policy and labour market practices: the case of overseas trained doctors. The Q13 Journal of Industrial Relations, 45,1, 67-86.

Groutsis, D. and Arnold, P.C. (2012) Tracking the career directions and experiences of migrant elites: the case of SouthAfrican-trained medical professionals in the Australian labour market. Health Sociology Review, 21,3, 332-42.

Hawthorne, L. (2005) 'Picking winners': the recent transformation of Australia's skilled migration policy. International Migration Review, 39,3, 663-96.

Hibbins, R. (2005) Migration and gender identity among Chinese skilled male migrants to Australia. Geoforum, $36,2,167-80$.

Higginbotham, E. (2012) Reflections on the early contributions of Patricia Hill Collins. Gender E Society, 26,1, $23-7$.

Ho, C. (2006) Migration as feminisation? Chinese women's experiences of work and family in Australia. Journal of Ethics Migration Studies, 32,3, 497-514.

Ho, C. an 2 orso, C. (2004) Migrants and employment: challenging the success story. Journal of Sociology, 40,3, 237-59-

hooks, b. (2001) Black women and feminism. In Arrighi B.A. (ed) Understanding inequality: the intersection of race/ethnicity, class and gender. Maryland: Rowman \& Littlefield Publishers, 19-24.

Hugo, G. (1994) Introduction. In Wooden, M., Holton, R., Hugo, G. and Sloan, J. (eds) Australian immigration: a survey of the issues. Canberra, ACT: Bureau of Immigration and Population Research, pp. 1-29.

IOM (International Organization for Migration) (2010) IOM gender and migration news. Issue 34, April. Geneva: IOM. Available at: http://publications.iom.int/bookstore/free/gender_bulletin_apr10.pdf (last acc
November 2013).

Kofman, E. (2004) Gendered global migrations. International Journal of Feminist Politics, 6,4, 643-65-.

Kofman, E. (2005) Gender and skilled migrants: into and beyond the work place. Geoforum, 36, 149-54-.

Kofman, E. (2014) Towards a gendered evaluation of (highly) skilled immigration policies in Europe. International Migration, 53,3, 116-28.

Kofman, E. and Raghuram, P. (2006) Gender and global labour migrations: incorporating skilled workers. Antipode, 38,2, 282-303.

Lewis, G. (2009) Celebrating intersectionality: debates on a multi-faceted concept in gender studies: themes from a conference. European Journal of Women's Studies, 16,3, 203-10.

Liversage, A. (2009) Vital conjunctures, shifting horizons: High-skilled female immigrants looking for work. Work, Employment \& Society, 23,1, 120-41.

MacKinnon, C.A. (2013) Intersectionality as method: a note. Signs, 38,4, 1019-30.

Mahuteau, S. and Junankar, P.N. (2008) Do migrants get good jobs in Australia? The role of ethnic networks in job search. The Economic Society of Australia, 84,S1, S115-S30.

Mann, S.A. (2013) Third wave feminism's unhappy marriage of poststructuralism and intersectionality theory. Journal of Feminist Scholarship, 4,spring, 54-73.

McCall, L. (2005) The complexity of intersectionality. Signs, 30,3, 1771-800.

Meares, C. (2010) A fine balance: women, work and skilled migration. Women's Studies International Forum, 33,5, 473-81.

Miller, T. (2011, Falling back into gender? Men's narratives and practices around first-time fatherhood. Sociology, 45,6, 1094-109.

Misko, J. (2012) The role of qualifications in foreign labour mobility in Australia. Adelaide: National Centre for Vocational Education Research.

Mushaben, J. (2009) Up the down staircase: redefining gender identities through migration and ethnic employment in Germany. Journal of Ethnic and Migration Studies, 35,8, 1249-74. 
Özbilgin, M.F., Beauregard, T.A., Tatli, A. \& Bell, M.P. (2011) Work-life, diversity and intersectionality: a critical review and research agenda. International Journal of Management Reviews, 13,2, 177-98.

Pedraza, S. (1991) Women and migration: the social consequences of gender. Review of Sociology, 17, 303-25.

Pocock, B. (2003) The work/life collision: what work is doing to Australians and what to do about it. Sydney: The Federation Press.

Pocock, B. (2005) Work-life 'balance' in Australia: limited progress, dim prospects. Asia Pacific Journal of Human Resources, 43,2, 198-209.

Raghuram, P. (2008) Migrant women in male-dominated sectors of the labour market: a research agenda. Population, Space and Place, 14,1, 43-57.

Rodriguez, J.K., Holvino, E., Fletcher, J.K. and Nkomo, S.M. (2016) The theory and praxis of intersectionality in work and organisations: Where do we go from here? Gender, Work and Organization, 23,3, $201-22$.

Sang, K., Al-Dajani, H. and Özbilgin, M. (2013) Frayed careers of migrant female professors in British academia: an intersectional perspective. Gender, Work and Organization, 20,2, 158-71.

Smith, D.P. (2004) An 'untied' research agenda for family migration: loosening the 'shackles' of the past. Journal of Ethnic and Migration Studies, 30,2, 263-82

Syed, J. (2008) Employment prospects for skilled migrants: a relational perspective. Human Resource Management Review, 18,1, 28-45.

Syed, J. and Murray, P. (2009) Combating the English language deficit: the labour market experiences of migrant woman in Australia. Human Resource Management Journal, 19,4, 413-32.

Tatli, A. and Özbilgin, M. (2012) An emic approach to intersectional study of diversity at work: a Bourdieuan framing. International Journal of Management Reviews, 14, 180-200.

Teicher, J., Shah, C. and Griffin, G. (2002) Australian immigration: the triumph of economics over prejudice? International Journal of Manpower, 23,3, 209-36.

Turner, T. (2010) The jobs immigrants do: issues of displacement and marginalisation in the Irish labour market. Work, Employment and Society, 24,2, pp. 318-36.

Vasta, E. (2005) Theoretical fashions in Australian immigration research. Working Paper No. 11, Oxford: Centre on Migration, Policy and Society, University of Oxford.

Walby, S. (2011) Globalization and multiple inequalities. Advances in Gender Research, 15, 17-33.

Weber, L. (2010) Understanding race, class, gender, and sexuality: a conceptual framework ( ${ }^{\text {nd }}$ edn). New York, NY: Oxford University Press.

Webb, S., Beale, D. and Faine, M. (2013) Skilled migrant women in regional Australia: promoting social inclusion through vocational training. Adelaide: National Centre of Vocational Education and Training.

West, C. and Fenstermaker, S. (1995) Doing difference. Gender E Society, 9,1, 8-37.

Wooden, M. (1994) The labour-market experience of immigrants. In Wooden, M., Holton, R., Hugo, G. and Sloan, J. (eds) Australian immigration: a survey of the issues. Canberra, ACT: Bureau of Immigration and Population Research, pp. 218-79.

Wright, T. (2016) Women's experience of workplace interactions in male-dominated work: The intersections of gender, sexuality and occupational group. Gender, Work and Organization, 23,3, 348-62.

Zaiceva, A. (2010) East-West migration and gender: is there a differential effect for migrant women? Labour Economics, 17,2, 443-54.

\section{Biographical notes}

Susan Ressia is a Lecturer within the Department of Employment Relations and Human Resources at Griffith University, Brisbane, Australia. Her recent doctoral research focused on the job search experiences of independent non-English speaking background skilled migrants in Australia. Susan's research interests also include the areas of work-life balance, managing diversity, equality and social justice issues.

Glenda Strachan is Professor Emeritus in the Department of Employment Relations and Human Resources Griffith University, Brisbane, Australia. Her research interests centre on contemporary and historical workplace change especially issues relating to wome rorking experience. The impact of organisational and national employment policies, especially E 2 nd diversity management, is a focus Q3 of her work. She is co-author of Managing Diversity in Australia: Theory and Practice, published in 2010.

Janis Bailey is an adjunct Associate Professor with the Department of Employment Relations and Human Resources, Griffith University, Gold Coast, Australia and is a member of the university's Centre for Work, Organisation and Wellbeing. Her research interests include union strategy and campaigning, vulnerable workers including youth and women, and teaching and lec $\mathrm{g}$ in business. She is currently working on projects on developing professional identity in ER a $P$ HR gradu- Q4 ates, and gender equity in universities. 